УДК 504.5/7; 619:616/618-091

(C) 2014

\author{
Цвіліховський М. І., доктор біологічних наук, \\ Береза В. І., кандидат ветеринарних наук, \\ Немова Т. В., кандидат ветеринарних наук, \\ Якимчук О. М., кандидат біологічних наук
}

Національний університет біоресурсів і природокористування України

\title{
ЛІМІТНІ ФАКТОРИ І ПАТОЛОГІЯ ТВАРИН АНТЕНАТАЛЬНОГО ТА ПОСТНАТАЛЬНОГО РОЗВИТКУ
}

\section{Рецензент - доктор ветеринарних наук, професор П. І. Локес}

\begin{abstract}
Наведено взаємодію лімітних факторів і показано їх роль у виникненні патологій антенатального та постнатального періодів розвитку тварин. Встановлено, щуо рівні екологічних факторів, які знаходяться за межами мінімальних або максимальних значень, призводять до різного виду порушень в організмі тварин. Екологічні фактори впливають на організм тварин не розрізнено, а комплексно, в різних співвідношеннях. Встановлено, щзо антенатальна патологія розвитку тварин є побічним негативним наслідком «неекологічної діяльності» людини в тваринництві.
\end{abstract}

Ключові слова: екологічні фактори, біоценоз, антенатальна патологія, постнатальна патологія.

Постановка проблеми. Життєдіяльність тварин, їх продуктивність, відтворювальна здатність, стійкість і сприйнятливість до захворювань визначаються впливом багатьох факторів природного середовища, що мають прямий або опосередкований вплив на організм. Ці фактори багаточисельні, різноманітні й за характером впливу на організм тварин не рівноцінні.

Зміни в екології та біоценозах у сучасних умовах розвитку тваринництва $є$ досить актуальними в процесі діагностики хвороб тварин. Тому виникає необхідність у проведенні екологічної оцінки біоценозів з урахуванням лімітних факторів у виникненні патології в тварин антенатального й постнатального періодів розвитку.

Аналіз основних досліджень і публікацій, у яких започатковано розв'язання проблеми. Для тварин різних видів $є$ свої, найбільш сприятливі, межі інтенсивності впливу екологічного фактора. Це оптимум, який займає середнє (або ближче до нього) положення в оптимальній зоні, а саме: оптимальні дози вітамінів, макро- і мікроелементів, перетравного протеїну та інших поживних речовин [3].

Лімітні фактори - це фактора природного середовища, що є дефіцитними, знаходяться нижче критичного рівня або, навпаки, в надлишку, перевищуючи необхідний для організму тварин рівень. Мінімум і максимум інтенсивності дії екологічного фактора на організм тварин визначають межі витривалості виду.

Поняття про мінімум, максимум, оптимум i дози впливу екологічного фактора в тваринництві може бути застосовано не тільки до поживних речовин, а й до інших елементів природного середовища: температури, світла, вологості повітря тощо.

3 метою прогнозування патологій тварин антенатального і постнатального розвитку фахівцям тваринницьких господарств різних форм власності слід чітко аналізувати й обгрунтовувати дію та співвідношення екологічних, етіологічних і стресових факторів. До того ж необхідно пам'ятати, що екологічні фактори впливають на організм тварин не розрізнено, а комплексно, в різних співвідношеннях.

Так, наприклад, науково обгрунтовано, що порушення вологості повітря і температурного режиму приміщень призводить до змін терморегуляції у тварин, розладів у них діяльності системи дихання (тахіпное) і серцево-судинної системи (тахікардія), розвитку симптомів ацидозу, риніту, ларингіту, бронхіту, бронхопневмонії, особливо в разі накопичення в повітрі приміщень значної кількості продуктів розпаду сечі та калу. В подальшому це призводить до гіпоксемії, особливо у молодняку тварин. За недостатності ультрафіолетових променів у тварин розвивається рахіт і остеодистрофія, а за обмеження моціону гіпокінезія, що супроводжується гіпотонією, порушенням кровообігу, зниженням нервовом'язового тонусу, дистрофією міокарда і хворобами кінцівок [3, 4].

Той чи інший екологічний фактор, що діє в незначній (дефіцитній) або надто великій (надлишковій) дозах, викликає у тварин стрес, що призводить до виникнення розладів травлення, порушень обміну речовин, аліментарних захворювань (гіповітамінози, мікроелементози, міне- 
ВЕТЕРИНАРНА МЕДИЦИНА

ральне голодування тощо) [6].

Метою даної роботи було проведення екологічної оцінки біоценозів з урахуванням лімітних факторів у виникненні патології в тварин антенатального і постнатального періодів розвитку.

Завдання дослідження: провести екологічну оцінку біоценозів; встановити та дослідити лімітні фактори у виникненні різної патології в тварин антенатального і постнатального періодів розвитку.

Матеріали і методи дослідження: клінічні, статистичні.

Результати досліджень. За нашими спостереженнями, в багатьох випадках стрес $є$ фазою переходу від здорового стану організму до хвороби. Етіопатогенетичні механізми цих порушень слід обгрунтовувати, враховуючи участь факторів біогеоценозу, так як із появою функціональних змін розвиваються дистрофічні процеси в органах і системах організму тварин, від яких народжується неповноцінний приплід (тварини-гіпотрофіки), сприйнятливий до шлунковокишкових і респіраторних захворювань [2].

У дослідженні цих механізмів у тваринництві ми враховували антропологічний фактор, який пов'язаний із плановою, випадковою, нинішньою чи минулою діяльністю людини. Прямий вплив людини на тварину (нераціональні експлуатація, утримання, годівля, вакцинація, лікування тощо) $є$ причиною виникнення захворювань у тварин [7, 9].

У випадках, коли людина впливає на популяції тварин (внутрішньопопуляційні взаємопорушення, нефізіологічне підвищення продуктивності, відтворювальних можливостей тощо), це призводить до таких розладів, як материнський післяродовий або лактаційний психоз, а у новонароджених тварин - до відсутності рефлексу смоктання. Такі патологічні зміни негативно впливають на стан тварин-матерів, у яких порушується молокоутворення і молоковіддача, що впливає на виникнення маститів та інших хвороб вимені, а в новонароджених тварин може стати причиною розладів травлення й порушення обміну речовин. Так, наприклад, за даними Б. М. Анохіна та ін. [1], порушення взаємозв'язку між свиноматкою і поросятами призводить до стресу й розвитку вегетоневрозів, що супроводжуються тахікардією та розладами шлунково-кишкового тракту. У свинарстві (де концентрація тварин має важливе значення) зв'язані зі стресом хвороби займають великий відсоток: у свиней виникає шок, виразка шлунку, розвиваються поліпатології, що проявляються еозинопенією, лімфоцитопенією, підвищенням рівня кортикальних гормонів у крові, збільшенням надниркових залоз.

Останнім часом, за нашими спостереженнями, у хворих свиней спочатку виявляється реакція на стрес, а саме: дрижання хвоста, задишка, підвищення температури тіла, локалізована гіперемія шкіри, серцево-судинна недостатність [3, 4].

У свиней зареєстрована хвороба під назвою «водяниста свинина», за якої в організмі тварин відбувається швидке розщеплення глюкози до молочної кислоти, вуглекислого газу й води, виникає гіпертермія, порушується рівновага в системі гістамін-гормони надниркових залоз. Спостереження свідчать, що частота виникнення цього захворювання пов'язана зі збільшенням концентрації поголів'я свиней на малих площах $\mathrm{i}$ їх породою.

За даними літератури [5], в Данії значний процент свинини, отриманий при забої свиней породи пьєтрен, бракується як «водяниста і біла». Найбільша летальність свиней цієї породи спостерігається внаслідок паралічу серця.

Пізнання дослідників щодо виникнення антенатальної патології в тварин, яка проявляється у формі вроджених вад (аномалій) розвитку і каліцтв, є неповними. Це пояснюється складністю діагностики патологічних змін у гаметах, зиготі, ембріоні й тканинах плода. Непрямим підтвердженням цього $є$ дані про безплідність, аборти, народження тварин-гіпотрофіків із анатомофізіологічними дефектами в різних органах і системах організму.

Аналіз даних літератури, результатів наших власних досліджень і багатолітніх спостережень свідчить про те, що причиною вроджених вад розвитку тварин можуть бути негативні лімітні фактори та зміни в біогеоценозах і їх складових компонентах (грунті, воді, рослинах, популяціях тощо). Серед компонентів біогеоценозу, що мають негативний вплив на антенатальний розвиток тварин, особливе місце відводиться організму тварин-матерів, які хворіють тою чи іншою хворобою, викликаною лімітними екологічними факторами. Порушення вагітності в самок і виникнення вад розвитку у зародків і новонароджених тварин виникають за гіповітамінозів А, В1, В2, D, Е, патології щитоподібної залози (зоб), білом'язовій хворобі, гіпоксемії, анемії, серцево-судинній недостатності, гострому та хронічному ендометритах, дистрофічних змінах слизової та м'язової оболонок матки, ушкодженні плаценти, плодових оболонок, вадах хоріона тощо. У дослідах на свинях було доведено, що несвоєчасне покриття кнуром свиноматки («перезрівання охоти») характеризується збільшен- 


\section{ВЕТЕРИНАРНА МЕДИЦИНА}

ням кількості абортів та підвищенням відсотку плодів із вираженими вадами розвитку [2].

Випадки каліцтва новонароджених встановленні у разі близькородинного розведення, порушення селекції та штучного відбору тварин [6].

Отже, антенатальна патологія розвитку тварин $є$ побічним негативним наслідком «неекологічної діяльності» людини в тваринництві.

Незважаючи на те, що чіткі статистичні дані про поширеність вроджених вад у сільськогосподарських тварин майже відсутні, й тератологія тварин знаходиться за межами сфери діяльності фахівців ветеринарної медицини, очевидним є те, що патологія антенатального і раннього постнатального розвитку тварин у різних біогеохімічних зонах має значне поширення, будучи одним із важливих факторів, що впливає на розвиток тваринництва.

Непрямим підтвердженням такого висновку можуть також бути дані про безпліддя тварин, аборти, частоту народження телят, поросят, ягнят - гіпортрофіків 3 анатомо-фізіологічними дефектами в легенях, шлунку, кишечнику та інших органах. Так, у господарствах різних форм власності в різних біогеохімічних зонах України за гіпотрофії новонароджених тварин нами було виявлено недорозвиненість грудної клітки, гіпо-

\section{БІБЛІОГРАФІЯ}

1. Анохин Б. М. Внутренние незаразные болезни сельскохозяйственных животных / Б. М. Анохин, В. М. Данилевский, Л. Г Замарин. - М. : Агропромиздат, 1991. - $575 \mathrm{c}$.

2. Береза В. I. Співвідношення екологічних, етіологічних і стресових факторів та їх вплив на розвиток біоценотичної патології у тварин / В. І. Береза, I. Г. Погурський, О. М. Якимчук [та ін.] // В кн.: Конференція проф.-викл. складу і аспір. ННІ ветеринарної медицини, якості i безпеки продукції АПК. - 03-04 березня 2005 р. - НАУ, Київ, Україна. - К. : Вид. центр НАУ, 2005. - С. 12-13.

3. Вержиховський О. М. Профілактика метаболічних порушень у свиноматок і лікування поросят за диспепсії та гастроентериту : автореф. дис. ... канд. вет. наук : 16.00.01 / О. М. Вержиховський; Нац. ун-т біоресурсів і природокористування України. - К., 2010. -24 c.

4. Грушанська Н. Г. Лікування і профілактика аліментарної анемії поросят 3 використанням комплексу органічних сполук мікроелементів: автореф. дис. ... канд. вет. наук: 16.00.01 / Н. Г. Грушанська; Нац. аграр. ун-т. - К., 2006. - 21 с.

5. Дикун А. Високоприбуткове свинарство: погляд на Данію / А. Дикун // Пропозиція. - 2009. № 5. - С. 126-127. вітамінози, ателектази і гіпостази в легенях, слизові пробки в бронхах. До того ж смоктальний рефлекс у тварин був слабким або відсутнім, секреторна, моторна та евакуаторна функції шлунка і кишок послаблені, в крові знижені показники вмісту гемоглобіну і кількості еритроцитів, диспротеїнемія, особливо значне зниження вмісту в сироватці крові $\gamma$-глобулінів, залізодефіцитна анемія в поросят перебігала тяжко і тривалий час $[3,4]$.

Висновок. Підсумовуючи результати наших досліджень і враховуючи дані літератури, вважаємо за доцільне у подальшому більш поглиблено вивчати лімітні фактори та їх роль у виникненні патологіі тварин антенатального і раннього постнатального розвитку. У процесі діагностики хвороб незаразної етіології в тварин у господарствах різних біогеохімічних зон України фахівцям ветеринарної медицини доцільно проводити екологічну оцінку тварин і біогеоценозів, використовуючи схеми диспансерного обстеження.

Виконання вказаних рекомендацій фахівцями ветеринарної медицини дасть можливість розробити й впровадити у виробництво обгрунтовані методи профілактики захворювань із метою створення здорових стад високопродуктивних тварин.

6. Чумаченко В. В. Технологічні аспекти системи профілактики стресу у свиней / В. В. Чумаченко, В. Ю. Чумаченко. // В кн. : Конфер. проф.-викл. складу, наук. співр. і аспір. ННІ ветеринарної медицини та якості і безпеки продукції тваринництва (05-06 квітня 2006 р.) - К. : Вид. центр НАУ, 2006. - C. 12-13.

7. Цвіліховський М. I. Діагностика, лікування та профілактика незаразних хвороб тварин / М. І. Цвіліховський, В. Ю. Чумаченко, В. І. Береза // Монографія: Наукове забезпечення сталого розвитку сільського господарства в Лісостепу України. - К. : Алефа, 2003. - Т. 2. - С. 165-181.

8. Цвіліховський M.I. Діагностика, лікування та профілактика незаразних хвороб тварин/ М. І. Цвіліховський, В. Ю.Чумаченко, В. І. Береза / В кн. : Наукове забезпечення сталого розвитку сільського господарства в Поліссі України. Монографія. - К. : Алефа, 2004. - С. 589-611.

9. Цвіліховський М. І. Внутрішні хвороби тварин / М. І. Цвіліховський, В. Ю. Чумаченко, В. І. Береза // В кн. : Наукове забезпечення сталого розвитку сільського господарства в Степу України i АР Крим, Кабінет Міністрів України, Національний аграрний університет. - К. : Алефа, 2005. - Т. 2. C. 679-698. 